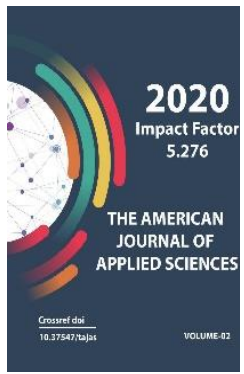

Copyright: Original content from this work may be used under the terms of the creative commons attributes 4.0 licence.

\section{Description Of Vehicle Operating Conditions And Their Impact On The Technical Condition Of Vehicles}

Ikromov Ikboljon Abdukhalilovich

Senior Lecturer, Department Of Land Transport Systems And Their Exploitation, Fergana Polytechnic Institute, Uzbekistan

Javlon Akhunov Abdujalilovich

Assistant, Department Of Land Transport Systems And Their Exploitation, Fergana Polytechnic Institute, Uzbekistan

\title{
ABSTRACT
}

The article provides examples of changes in the technical operation of vehicles, their application and use, as well as the impact on the technical condition of vehicles.

\section{KEYWORDS}

Machine, motor mechanism, technical condition, movement, wear, operation.

\section{INTRODUCTION}

This article does not allow us to imagine our life today without vehicles.

Whereas before the car was a luxury, today it has become a compact, fast-moving, inexpensive, everyday commodity, lightening the weight of people, making it closer and more, and other advantages are becoming more and more durable in our lives[1,2,3].

The technical condition of the car is very important in the process of its maintenance. These indicators are, firstly, a tool that monitors the condition of the car and 
determines the amount of adjustment and repair work, and secondly, a tool for predicting a technical resource, i.e. predicting a reserve of uninterrupted operation until the next maintenance.

Therefore, it is necessary to know the limiting norms of indicators of technical condition and the dynamics of their change depending on the road, because according to the laws of change in indicators, it is possible to determine the resource until the next maintenance.

\section{MATERIALS AND METHODS}

As the service life of a car increases, its technical condition gradually deteriorates as a result of wear of parts: engine power and technical speed of movement decrease, fuel consumption and wear rate increase, usability deteriorates, the volume of maintenance and repairs increases, and reliability decreases.

The technical condition of the vehicle is influenced by many operational factors. The main ones are:

- The quality of operating materials (gasoline, diesel fuel, gaseous fuel, lubricants, special fluids - antifreeze, brake fluid, etc.);

- Road conditions;

- Climatic conditions;

- The technical operation of the vehicle (power consumption mode, driving performance);

- Quality of service;

- The quality of car storage, etc.

The main requirement for fuels and lubricants is their compliance with state standards and vehicle engine design, as well as climatic conditions and vehicle operating modes [4]. Thus, fuels are divided into models according to function (for carburettor and diesel engines for summer and winter use) and quality (octane and cetane number). Fuel and lubricants affect vehicle performance such as fuel economy, reliability, engine power, speed. Maintaining the quality of fuels and lubricants is very important during their transportation, storage and distribution.

The main properties of gasoline are volatility (fractional composition), detonation and corrosive properties, as well as the absence of mechanical impurities and water. Its anti-knock properties are enhanced by the use of special anti-knock agents $[5,6]$. The presence of sulfur in gasoline causes corrosion and mechanical wear of the cylinder-piston group and valves. The higher the sulfur content, the higher the wear rate and fuel consumption of the engine cylinders and the lower the engine power.

Mechanical contamination in the fuel contaminates the carburettor components, making it difficult to form a fuel mixture, impairing the vehicle's traction and fuel economy. Most importantly, the mechanical compounds increase the wear rate of the cylinder-piston group of the engine.

Diesel fuel qualities such as the amount of cetane, viscosity, evaporation, corrosion properties and the presence of mechanical impurities affect the performance of the vehicle[7]. If the amount of cetane strongly affects the durability and fuel economy of the engine, the fuel bucket causes it to spray, form a mixture with air and ignite, as well as abrasion of thin vapours in the fuel equipment.

The corrosion characteristic of diesel fuel depends on the amount of sulfur contained in it: the more it is, the more corrosionmechanical destruction of engine cylinders and piston rings occurs. The absorption increases, especially at low temperatures of the engine. The presence of mechanical impurities in the diesel fuel composition leads to the fact that 
thin vapours in the fuel supply equipment break up[8]. The easiest way to separate mechanical impurities from diesel fuel is to cast it within a few days.

Gas fuels are of high performance. Their use reduces engine wear, ensures detonation-free operation, reduces the toxicity of exhaust gases, and extends the life of the engine oil.

During operation, it is necessary to prevent fuel evaporation during use, storage, transportation and distribution in accordance with the engine design, natural and climatic conditions and regulatory requirements, ensure the absence of mechanical impurities and water. Lubricants (for example, fuel) are also classified and standardized by function (crankcase oils for carburettor and diesel engines, transmission oils), by quality (a type of cleaning, viscosity, additives, etc.).

Lubricants and lubricants are used to provide liquid or boundary friction, reduce friction work and wear, remove heat from friction pairs, wear products from cracks, seal cracks, and protect lubricated surfaces from corrosion. Engine oil works at high temperatures and certain pressures. This can lead to the formation of rust products, tar and residues. Its main performance properties are viscosity, resistance to washing and corrosion, absence of mechanical impurities and water. Improving the performance of engine oils is achieved by adding various chemicals (compounds) to them[6-9]. The hinges reduce the wear rate of rubbing parts by at least half.

\section{CONCLUSION}

When using vehicles - the quality of the operating materials, - the road conditions, - the climatic conditions, - the technical operation of the vehicle (energy consumption modes, the driving quality), - the quality of service, - the prevention of further changes in the performance properties of the vehicle in addition to its storage properties. The technical condition of the car is very important in the process of its maintenance, as it depends both on the driver and on his skills.

\section{REFERENCES}

1. The technical operation of cars. Translated from the 4th edition of the revised and supplemented Russian (edited by prof. Kuznetsov E.S., M.: Nauka, 2004, p. 535). Sidiqnazarov Q.M. under the general editorship, Tashkent "VORIS" publishing house, 2006. $670 \mathrm{p}$.

2. The technical operation of cars. The Ministry of Higher and Secondary Special Education of the Republic of Uzbekistan has recommended motor transport as a textbook for students of higher educational institutions. Prof. Sidiqnazarov Q.M. under the general editorship, Tashkent "VORIS" publishing house, 2008. p.560.

3. The technical operation of vehicles. (2001). Textbook for Universities. Ed. Prof. E.S. Kuznetsova. Moscow: Science.

4. Hamraqulov O., Magdiyev Sh. (2005). The technical operation of cars. Tashkent.

5. Barovskikh Yu.l. et al. (2001). Construction, maintenance and repair of cars. Tashkent: "Labor".

6. Abdukhalilovich, I. I., \& Obloyorovich, M. H. (2020). Support for vehicle maintenance. Asian Journal of Multidimensional Research (AJMR), 9(6), 165-171.

7. http://www.autosib.com/aroundauto/detail/3415.html 
The American Journal of Applied Sciences (ISSN - 2689-0992)

Published: October 30, 2020 | Pages: 37-40

8. http://www.znaj.ru/referats/transport/

9. http://revolution.allbest.ru/transport/o

0048708.html 